\title{
APPLICATION OF GLOBAL MODELS OF ECO-DEVELOPMENT IN UKRAINE
}

\author{
Ostap Khalavka'
}

\begin{abstract}
The purpose of the paper is to analyze the successful experience of both developing and developed countries related to the resolution of environmental issues and implementation of the models of eco-development and provide recommendation for Ukraine regarding the ways to apply this experience in the country's economy effectively. Methodology. The paper is based on the combination of qualitative and quantitative research and applies the dialectic perception method to analyze economic events and processes at the time of their development, interconnection, and interdependence. Results of the research demonstrate that successful sustainable transformation of the economy may take place not only in highly developed countries but also in the developing ones. Ukraine may consider the successful experience of the implementation of sustainable initiatives of such countries as Luxembourg, Denmark, Switzerland, Seychelles, and Morocco. The success of these countries is addressing environmental issues is related to their focus on establishing cooperation between the public and private sectors while promoting sustainable behavior among citizens. The government of Ukraine needs to prioritize sustainable transformation of the economy by improving the country's business climate for innovative sustainable startups and by promoting the development and application by businesses of energy-efficient technologies. The main potential challenges that may be faced by Ukraine in its way towards sustainable development are corruption and ineffective use of financial resources, however, these issues may be addressed via the cooperation with international organizations. Sustainable transformation of the Ukrainian economy will not only improve the environmental situation in the country but will also create visible benefits for economic players and people. Practical implications. The environmental situation in Ukraine has been deteriorating for decades and the previously applied as well as existing measures implemented to address environmental issues in Ukraine do not provide desired outcomes. The country needs to apply new innovative instruments and measures to make it economy sustainable and, to this end, Ukraine should create the economic conditions in which sustainable development would be beneficial for all engaged parties. The practical experience of both developed and developing countries has the potential to be implemented in Ukraine in coming years in case the country's authorities take appropriate and timely measures. Value/originality. The provided recommendations for Ukraine consider the modern trends and conditions existing in the global economy, have regard to the successful experience of sustainable transformation of the economy, in particular, of developed and developing countries, and may be used by the country's government to develop effective sustainable development policy in the future.
\end{abstract}

Key words: eco-development, environmental challenges, developed and developing countries, sustainable transformation of the economy, transport, technologies, urbanization.

JEL Classification: Q01, Q55, R11, 018, O30

\section{Introduction}

In the modern globalized world, the competitiveness of a country is determined based not only on the value of its economic indicators but also on its sustainability. The economy of Ukraine cannot be considered as sustainable since the country is facing significant environmental challenges related to air and water pollution,

\footnotetext{
Corresponding author:

${ }^{1}$ Institute of International Relations,

Taras Shevchenko National University of Kyiv, Ukraine.

E-mail: ostapkhalavka@gmail.com
}

lack of the protection of ecosystems, ineffective waste management, and other issues. The country needs to take immediate actions to address its environmental problems and create the conditions for sustainable development of the economy. The experience of developing related to the successful environmental transformation of the economy has not been considered enough in Ukraine and, thus, 
the provided recommendation may be innovative and unique for the country's policymakers. The current paper aims to analyze the global experience of dealing with environmental issues that has a potential to be applied in Ukraine, taking into account the country's resource base and technological development level.

\section{Experience of developed} and developing countries related to addressing environmental challenges

Although the global community has not achieved its environmental and economic objectives provided by United Nations (UN) Sustainable Development Goals, a group of countries has successfully implemented the models of ecodevelopment and has achieved progress in field of addressing the issues related to climate change. It is of the greatest importance for developing countries to consider the expertise of the developed countries related to environmental transformation of the economy and they should strive to apply the best practices under the existing technologies and resources. Let us analyze the experience of successful implementation of the models of sustainable growth by the countries that are the leaders of the ranking of countries according to their progress related to the implementation of Sustainable Development Goals.

Table 1

\section{Ranking of countries according}

to their progress related to the implementation of Sustainable Development Goals, 2019

(Sustainable Development Report, 2020)

\begin{tabular}{|c|c|c|}
\hline Rank & Country & Score \\
\hline 1 & Sweden & 84.72 \\
\hline 2 & Denmark & 84.56 \\
\hline 3 & Finland & 83.77 \\
\hline 4 & France & 81.13 \\
\hline 5 & Germany & 80.77 \\
\hline 6 & Norway & 80.76 \\
\hline 7 & Austria & 80.70 \\
\hline 8 & Czech Republic & 80.58 \\
\hline 9 & Netherlands & 80.37 \\
\hline 10 & Estonia & 80.06 \\
\hline 15 & Switzerland & 79.35 \\
\hline 44 & Luxembourg & 74.31 \\
\hline
\end{tabular}

Switzerland: the government of Switzerland conducts innovative environmental policy. The model of green economy applied by this country is focused on 3 main aspects including rational consumption, green energy, and waste recycling (Footprint Network, 2016). Switzerland is actively applying the taxation of carbon emissions. The tax on carbon emissions increases the prices of goods and services, the production of which causes these emissions. As a result, the consumers of these goods and services are becoming motivated to consume more sustainable alternatives due to price considerations. The government of Switzerland also realizes that urbanization causes significant negative implications for the environment. To address these implications, the government of Switzerland adheres to the principles of strategic planning of the country's territory and protects fundamental natural ecosystems from anthropogenic interference. Via the implementation of the policy of limited urbanization, Switzerland has preserved its green territories and improved the quality of water in lakes and rivers. The economic losses occurred due to the limited urbanization are compensated by the development of tourism and agriculture. Switzerland is also the first country in the world that has launched the factory that extracts carbon from the air (Marshall, 2017). The government of Switzerland actively promotes innovations and scientific development in the field of sustainable growth. For the last 10 years, more than 200 innovative environmental startups have appeared in Switzerland and this country is the global leader in terms of the number of environmental patents per capita: Switzerland has more than 4000 environmental patents per capita (House of Switzerland, 2020). It is also important to mention that the local governments of Switzerland actively conduct the certification policy and reward to the cities that have succeeded in the field of sustainable growth. As a result, the cities that get environmental rewards become more attractive for doing business and tourism that has a positive impact on their economies.

Denmark: when carrying out environmental transformation, the government of Denmark pays a particular attention to the improvement of quality of water resources by cleaning used water. Denmark protects water ecosystem via the functioning of more than 1000 water-cleaning facilities (The Danish Environmental Protection Agency, 2020). Taking into consideration the importance of maintenance of the water-cleaning facilities, the price of water in Denmark is one of the highest in the world, however, such high prices make citizens 
and business consume water rationally. Denmark is one of the global leaders in the field of safe waste recycling and conducts an active environmental modification of transport that provides for the substitution of petrol public transport with electric vehicles and promotion among the population the culture of using individual electric vehicles including electric cars and electric scooters. In the business level, the government of Denmark prioritizes the environmental development of logistics by encouraging companies to use effective technologies that do not cause the emission of carbon in the atmosphere.

Luxembourg: the government of Luxembourg is implementing the program aimed at the preservation of water resources that provides for the provision of subsidies to farmers and businesses that take measures to mitigate the pollution of groundwater. The government of this country is also cutting financing of entities that do business in the field of cleaning of industrial wastewater but also to this end out-of-date equipment. Thus, the government of this country established the system of motivation for highly efficient and innovative water-cleaning entities. The government of Luxembourg actively develops protected water areas and, currently, there are 10 such areas in the country and the government plans to increase this number to 30 in the coming years (Government of Luxembourg, 2020). Luxembourg is one of the global leaders in terms of the rate of ecosystem recovery and this country is going to continue increasing the effectiveness of its environmental initiatives.

However, the progress of the most developed economies of the world in the field of sustainable

Table 2

Top 10 countries according

to their progress in the environmental performance index within the last 10 years

(Environmental Performance Index, 2020)

\begin{tabular}{|c|c|c|}
\hline Rank & Country & Change, $\%$ \\
\hline 1 & Bahrain & 17.3 \\
\hline 2 & Seychelles & 14.8 \\
\hline 3 & Croatia & 13.4 \\
\hline 4 & Morocco & 13.3 \\
\hline 5 & Kuwait & 12.8 \\
\hline 6 & Luxembourg & 11.6 \\
\hline 7 & Malta & 11.6 \\
\hline 8 & United Arab Emirates & 11.3 \\
\hline 9 & Jordan & 11.2 \\
\hline 10 & Oman & 11 \\
\hline
\end{tabular}

development does not constitute an unprecedented event, taking into account their material and financial capacities, scientific base, and expertise. Since Ukraine is not considered as one the most developed countries, it is reasonable to analyze the experience of the developing countries that have achieved significant progress for the last 10 years in the field of environmental transformation. To identify the most successful developing countries in this aspect, it is necessary to use the environmental performance index.

According to this index, the most significant progress among the developing countries, in terms of the rate of implementation of the ecodevelopment models, has been demonstrated by such countries as Seychelles, Morocco, Jordan, Albania, Namibia, Kazakhstan, and China. Let us consider cases of successful environmental transformation in the developing countries that has a high potential to be applied in Ukraine.

Seychelles: Seychelles is the first country in the world that has embedded the protection of environment in the country's Constitution. The government of this country contributes significant efforts to protect the water ecosystem that suffers from the negative implications of illegal fishing and waste pollution. The authority of Seychelles is going to introduce the Water territorial plan that provides for the creation of protected water territories the area of which will be bigger than anywhere in the world, except of Norway. The government of Seychelles strives to ensure balance between economic growth driven by tourism and exploitation of water resources and preservation of ecosystems. The area of the protected water territory will constitute 30 per cent of the country's total water territory (State House, 2020). Via the implementation of these environmental practices, Seychelles has already achieved and even outperformed its obligations taken within the UN Convention on Biological Diversity that provide for the protection of at least 10 per cent of country's water territory. The economic strategy of Seychelles is based on the concept of Blue Economy that provides for the search for innovative solutions to boost economic growth while ensuring the preservation of environment. Seychelles is the global pioneer in the field of issuance of Blue Sovereign Bonds. The Blue Sovereign Bonds are issued to get financial resources for local communities and businesses to give them an opportunity to protect water areas and create the conditions for making their 
activities sustainable. The Blue Sovereign Bonds are considered as an innovative financial instrument that is used by investors that are interested in funding projects aimed at the protection of the resources of the ocean. Seychelles use this financial instrument since the country is heavily dependent on the water resources since fish products account for 95 per cent of the country's merchandise export (Food and Agriculture Organization, 2014). The value of the Blue Sovereign Bonds issued by Seychelles is $15 \mathrm{mln}$ USD and the maturity duration is 10 years. The issuance of these obligations has been carried out under the supervision of the World Bank and the Global Ecologic Forum and the latter has assumed the responsibility for making coupon payments (The World Bank, 2018). As a result, the cost of these bonds for Seychelles has decreased and the risks for investors have become limited. Generally, Seychelles has succeeded in getting affordable financial resources to protect the country's ecosystem.

Morocco: this country is considered as an African leader in the field of sustainable development. The country benefits from its geographic location by actively increasing the role of renewable energy such as solar and wind energy in its energy balance. The state provides financial support to the private companies that produce electricity from the energy of the Sun. Taking into account a tremendous deficit of drinking water, the government of Morocco actively cooperates with the international organizations such as the World Bank to get financing for the construction of water-cleaning facilities and procurement of innovative technologies to reduce the level of water consumption in cities. A large waste sorting and recycling facility operates in the country's capital Rabat and its functioning mitigates the level of environmental pollution in the country and creates job places for the most vulnerable categories of people, thereby, addresses the problem of poverty.

In 2016, the government of Morocco has prohibited the import of waste despite potential economic losses from this decision (Alami, 2016). In terms of the system of education, educational programs and courses on the topic of eco-development have become mandatory both in the country's schools and in universities. The centers that promote eco-development have been established in 18 cities across the country and these centers organize different scientific events and invite citizens to participate in them. The government of
Morocco realizes that successful implementation of the concept of eco-development cannot take place unless small and medium-sized companies are engaged. To this end, the government of Morocco cooperates with private investors to develop the mechanisms of co-financial and financial guarantying of environmental initiatives.

Like Seychelles, the government of Morocco has used bonds to get resources to achieve the objectives of sustainable development, however, compared to Seychelles, Morocco has used Green Sovereign Bonds. For example, in 2016, Morocco carried out a few issuance of Green Bonds that value of which equaled to $260 \mathrm{mln}$ USD (Masen, 2018). The private issuance of bonds in Morocco is aimed at financial the projects in the field of renewable energy and energy efficiency. Morocco issues Green Bonds in cooperation with the International Financial Corporation.

All countries that have achieved progress in dealing with the issue of environmental pollution and implemented the models of eco-development have not only theoretically developed national environmental policies but have also effectively implemented them in practice. Generally, the effectiveness of a national environmental policy depends on the following factors:

- Development of a long-term strategy in co-operation with business and community;

- Identification of the basic environmental conditions and the determination of target qualitative indicators and control results;

- Identification of environmental issues with regard to existing and potential social and economic challenges;

- Cost analysis and estimation of benefits from the implementation of a national environmental policy;

- Conduct of monitoring during the policy implementation;

- Estimation of results to consider failures and achievements of the implemented environmental policy when developing future environmental strategies and models of eco-development.

The modern environmental situation in Ukraine may be described as crisis that is close to catastrophe. The issue of environmental degradation in Ukraine requires the implementation of immediate responsive mechanisms as well as the development of long-term strategies aimed at the prevention of environmental crises. The problem of environmental pollution in Ukraine has a national 
scale; however, an important role in addressing environmental threats is played by local authorities and communities since Ukraine has carried out the decentralization reform.

\section{Practical recommendations for Ukraine to make its economy sustainable}

Before proposing recommendation on the ways to address the issue of environmental pollution in Ukraine, it is reasonable to analyze the level of realization by Ukraine of the UN Sustainable Development Goals and identify problem fields. As of 2020, Ukraine has achieved planned progress in such areas as the protection of marine resources, partnership for sustainable development, rational consumption and production, and affordable and clean energy. However, Ukraine has not achieved enough progress in such areas as the provision of clean water and sanitation to people and sustainable development of cities and communities. Generally, as of 2020, there are no Sustainable Development Goals that are fully implemented in Ukraine (Derzhavna sluzhba statystyky Ukrainy, 2020).

One of the main sources of environmental pollution in Ukraine is the energy sector. The state should prioritize an increase in the share of renewable energy in the country's energy balance. However, the shift to alternative sources of energy should not distort competition or provide visible benefits to a particular market player or other entities. The use of energy produced from alternative sources should constitute a benefit for companies rather than an additional burden in the form of an increased price for electricity.

Ukraine should promote the implementation of energy-efficient technologies by providing affordable credits to businesses. Since the EU has introduced the carbon tax on imported products, the Ukrainian companies have a chance to gain competitive advantages over Asian and African exporters of goods and services to the EU by adopting the European environmental standards.

To mitigate the negative environmental effect of urbanization, Ukraine should create conditions for economic growth in the rural areas. The state needs to provide advisory and regulatory support to small and medium-sized companies doing business in rural areas to strengthen their competitiveness on both national and international markets. The issues faced by national companies when trying to enter foreign markets constitute one of the main reasons for low revenues received by small and mediumsized companies in rural areas. As a result, the employees working in these entities are forced to move to foreign countries to look for better-paid jobs. That is why the creation of highly paid jobs in rural areas should constitute one of the ways for Ukraine to ensure sustainable development of its economy.

One of the main tasks for Ukraine is the establishment of the mechanism of producers' responsibility for wastes that has to cover the utilization of such products as storage batteries, vehicles, tires, clothing, oil, electric and electronic equipment, and packaging. The separate collection of these wastes, their transportation and utilization have to financed not by citizens in the form of payment for waste management services but rather by producers of such products in the form of special fees. At the result of the implementation of this system, companies will be interested in ensuring a long exploitation period of their products and will try to minimize the amount of dangerous materials used in the production of such products (Ministerstvo rozvytku hromad ta terytorii Ukrainy, 2019). Besides, Ukraine should empower communities and municipal authorities to issue permits to construct and exploit facilities that recycle and safely utilize wastes to mitigate the corruption risks caused by the involvement of a state machine. Taking into account the experience of Morocco, Ukraine should actively invest funds to construct waste recycling facilities in cities to increase the efficiency of logistics and create job places for vulnerable categories of urban population (The World Bank, 2016). With regard to the modern socio-economic crisis in Ukraine, the construction of waste recycling facilities and plants should be included in the program of the President of Ukraine called Big Construction.

Taking into consideration the experience of the leading countries of the world related to addressing environmental threats and ensuring sustainable growth, Ukraine should develop attractive conditions and climate for the functioning of innovative environmental startups. To this end, Ukraine should not only eliminate the regulatory pressure on startups but also give them an opportunity to get affordable credits (within the program called 5-7-9) as well as non-refundable grant financing. Innovative environmental startups should become a driver of sustainable development in Ukraine. 
To preserve its water resources, Ukraine needs to actively develop and modernize the system of water-cleaning facilities and objects. On the legislative level, Ukraine needs to prohibit the use of phosphates in cleaning agents and introduce an effective and transparent system of responsibility for entities for non-authorized or illegal release of hazardous materials or uncleansed water into the water ecosystems. It would be reasonable for Ukraine to apply the model of Denmark that is focused on the construction of small and mediumsized water-cleaning facilities throughout the country rather than in its separate regions (The Danish Environmental Protection Agency, 2020). Besides, Ukraine should prioritize the creation of nature protection areas within the territories of main water reserves to improve the quality of drinking water consumed by citizens.

In cooperation with international financial institutions, Ukraine should implement the program of municipal transport development with a focus on the use of hybrid and electric vehicles (CIVITAS, 2019). Municipal transport should become attractive for the population and, to this end, the development of transport infrastructure including the creation of separate road lines for public transport and the prohibition for private vehicles to enter a city center are becoming extremely important. When modifying the system of municipal transport, the government needs to focus its efforts not only on the development of intra-city public transport lines but also development the public transport system that would connect major cities with their satellites since, currently, all system of suburban transport in Ukraine is private and, due to corruption challenges, is not subject to proper environmental monitoring.

Ukraine should also consider the possibility to apply the expertise of Seychelles related to the issuance of environmental bonds. Seychelles has issued Blue Bonds and Ukraine should issue Green Sovereign Bonds to restore the country's ecosystem, construct and modernize the watercleaning facilities, launch waste recycling plants, and implement big energy-efficient projects (The World Bank, 2018). The issuance of Green Bonds will bring significant benefits for Ukraine since the country, when dealing with environmental challenges, faces such issues as the deficit of financial resources, the presence of large corruption schemes, and ineffective use of allocated funds. The issuance of Green Bonds will allow Ukraine to simultaneously address the abovementioned issues since this procedure is carried out under the monitoring of international financial institutions that thoroughly supervise the use of the allocated funds that prevents corruption and increases the efficiency of the use of funds.

At the time of rapid digital transformation in Ukraine, digital technologies may be applied by both the country's government and businesses to monitor and prevent environmental issues. Ukraine should actively develop interactive and reliable environmental pollution maps indicating the entities that cause the environmental pollution that exceeds the existing norms and standards. Via the application of digital technologies, the state will be able to immediately identify the violators of the environmental standards and norms and take corrective measures. By developing mobile applications focused on promoting sustainable behavior among users, the state and private innovative companies will be able to increase the level of public interest related to the resolution of environmental challenges and the implementation of eco-development models.

\section{Conclusion}

Overall, to address the existing environmental challenges and implement the model of sustainable development, Ukraine should carry out structural transformation of both the regulatory environment and business climate. With regard to the experience of other countries related to dealing with environmental issues and their prevention, Ukraine needs to contribute efforts and resources to protect water facilities by improving the water-cleaning infrastructure, get financing under the supervision of international organizations to implement large sustainable initiatives, and promote the participation of citizens in the programs and activities aimed at resolving the problem of environmental pollution. Moreover, Ukraine should prioritize the development of sustainable digital technologies that may enjoy a high popularity among businesses and common people. Successful implementation of the model of ecodevelopment in Ukraine cannot take place unless the state, business sector, and people realize the potential benefits for them from the sustainable economic growth in Ukraine. 


\section{References:}

Derzhavna sluzhba statystyky Ukrainy (2020). Tsili staloho rozvytku Ukrainy - Potochnyi prohres u rozrizi tsilei ta indykatoriv [Sustainable development goals of Ukraine - Current progress in terms of goals and indicators]. Kyiv: Informatsiino-analitychne ahentstvo.

Ministerstvo rozvytku hromad ta terytorii Ukrainy (2019). Pro rozshyrenu vidpovidalnist vyrobnyka tovarnoi produktsii u povodzhenni z pobutovymy vidkhodamy, - roziasnennia Minrehionu [About the extended responsibility of a producer of products related to waste management, - clarification from Minregion]. Available at: https://www.minregion.gov.ua/press/news/pro-rozshirenu-vidpovidalnistvirobnika-tovarnoyi-produktsiyi-u-povodzhenni-z-pobutovimi-vidhodami-roz-yasnennya-minregionu/ CIVITAS (2019). Electric and hybrid buses for public transport. Available at: http:/ / civitas.eu/measure/ electric-and-hybrid-buses-public-transport

The Danish Environmental Protection Agency (2020). Water at home. Available at: https://cutt.ly/ mkiF9Xb

The World Bank (2016). Morocco lets nothing go to waste. Available at: https://www.worldbank.org/ en/news/feature/2016/02/16/morocco-lets-nothing-go-to-waste

The World Bank (2018). Seychelles launches World's First Sovereign Blue Bond. Available at: https://www.worldbank.org/en/news/press-release/2018/10/29/seychelles-launches-worlds-firstsovereign-blue-bond

Alami, A. (2016). Going green: Morocco bans use of plastic bags. Aljazeera. Available at: https://cutt.ly/1kiF7B4

Environmental Performance Index (2020). 2020 EPI Results. Available at: https://epi.yale.edu/ epi-results/2020/component/epi

Food and Agriculture Organization (2014). Country Review Seychelles 2014. Available at: http://www.fao.org/3/a-br801e.pdf

Footprint Network (2016). How Switzerland made history with green economy vote. Available at: https://www.footprintnetwork.org/2016/09/26/switzerland-made-history-green-economy-vote/

Government of Luxembourg (2020). Reglemented drinking water protection zones. Available at: https://data.public.lu/en/datasets/reglemented-drinking-water-protection-zones/

House of Switzerland (2020). A future in protecting the environment. Available at: https://www.houseofswitzerland.org/swissstories/environment/future-protecting-environment

Marshall, C. (2017). In Switzerland, a giant new machine is sucking carbon directly from the air. Science Mag. Available at: https:/ www.sciencemag.org/news/2017/06/switzerland-giant-newmachine-sucking-carbon-directly-air

Masen (2018). Morocco is "very open" to more green bonds - Masen Chief. Available at: http://www.masen.ma/en/projects/morocco-very-open-more-green-bonds-\%E2\%80\%93-masen-chief Rabadi, A. (2016). The Red Sea-Dead Sea desalination project at Aqaba. Desalination and Water Treatment, vol. 57(48-49), pp. 22713-22717.

State House (2020). Seychelles designates $30 \%$ of its EEZ as marine protected area. Available at: http://www.statehouse.gov.sc/news/4787/seychelles-designates-30-of-its-eez-as-marine-protected-area Sustainable Development Report (2020). Rankings 2019. Available at: https://dashboards.sdgindex.org/ rankings

The Danish Environmental Protection Agency (2020). Water at home. Available at: https://cutt. ly/7kiGqhx 